\title{
Signifikansi Kebudayaan dalam Pendidikan: Refleksi Identitas Keberagaman Siswa di Ruang Kelas
}

\author{
Heni Rahmawati, Rosyidatul Afifah, Fitri Nur Cholifah, Arif Rahman \\ Universitas Ahmad Dahlan
}

\begin{tabular}{l} 
INFO ARTIKEL \\
\hline Riwayat Artikel: \\
Diterima: 29-12-2020 \\
Disetujui: 04-03-2021 \\
\hline
\end{tabular}

\section{Kata kunci:}

Keragaman Siswa

Multikultural

Pendidikan Multikultural

\author{
Alamat Korespondensi: \\ Heni Rahmawati \\ Pendidikan Agama Islam \\ Universitas Ahmad Dahlan \\ Jalan Ring Road Selatan, Tamanan, Banguntapan, Bantul Yogyakarta 55166 \\ E-mail: heni1800031190@webmail.uad.ac.id
}

\begin{abstract}
This study was conducted to gather sufficient information on the significance of culture in education by reflecting on the diversity identity of students in the classroom. The method used in this study is through the library (Library Search) which includes qualitative research carried out by reading literature, such as journals, books or magazines and other sources. The results of this study indicate that students in the classroom have a diversity of races, ethnicities, cultures, religions, languages, and groups, so multcultural education is very important to be reflected on students in the classroom, with this understanding it is hoped that students can carry out the Indonesian motto, "Bhinneka. Tunggal Ika ". The application of this multicultural understanding also requires a variety of strategies for students such as discussions, observations, case studies, simulations, role playing, and others. Based on the results of this library search, it can be concluded that there are three phases carried out to reflect on the diversity in the classroom, namely planning, implementation, and evaluation.

Abstrak: Studi ini dilakukan untuk mengumpulkan informasi yang cukup terhadap signifikasi kebudayaan dalam pendidikan dengan refleksi identitas keberagaman siswa diruang kelas. Metode yang digunakan dalam studi ini yaitu melalui kepustakaan (library search) yang termasuk penelitian kualitatif yang dilakukan dengan membaca literatur, seperti jurnal, buku, atau majalah dan sumber lainnya. Hasil dari studi ini menunjukkan bahwa siswa diruang kelas mempunyai keberagaman ras, etnis, budaya, agama, bahasa, dan golongan, maka pendidikan multikultural sangat penting untuk direfleksikan terhadap siswa diruang kelas, dengan pemahaman tersebut diharapkan siswa dapat melaksanakan semboyan bangsa Indonesia yaitu "Bhinneka Tunggal Ika". Penerapan paham multikultural ini juga diperlukan strategi yang beragam terhadap peserta didik seperti diskusi, observasi, studi kasus, simulasi, bermain peran, dan lain-lain. Berdasarkan hasil library search ini maka dapat disimpulkan bahwa ada tiga fase yang dilakukan untuk merefleksi keberagaman yang ada di dalam kelas yaitu perencanaan, pelaksanaan, dan evaluasi.
\end{abstract}

\section{PENDAHULUAN}

Indonesia adalah negara berbangsa-bangsa dan bersuku-suku merupakan negara multikultur terbesar yang berpenduduk terbanyak keempat di dunia. Dalam Islam di jelaskan tentang penciptaan manusia yang berbangsa- 
bangsa yaitu untuk saling mengenal dan menghormati antar budaya, ras dan agama sebagai realitas kemanusiaan. Namun tidak jarang seringkali terjadi konfik di dalam masyarakat karena terdapat berbagai pendapat dan pandangan yang menurut masing-masing mereka adalah yang paling benar. Konfik yang sering terjadi perlunya signifikansi pemahaman multikultural dalam proses pendidikan pendidikan (Aziz, 2020).

Pendidikan yaitu suatu proses pengembangan kemampuan sosial dan perkembangan individu yang optimal sehingga dapat memberikan relasi yang kuat antara individu dan masyarakat. Pendidikan mempunyai keterkaitan dengan budaya karena didalalam pendidikan terdapat tujuan yaitu mengasah rasa, karsa dan karya. Dalam pendidikan menuai akan mengalami tantangan sepanjang masa, salah satunya yaitu keanekaragaman budaya. Dengan adanya perbedaan budaya maka diperlukan adanya sikap toleransi dan saling menghormati agar menjadikan suatu kerukunan di dalamnya (Purnamasari, 2017).

Agama Islam merupakan agama Rahmatallil 'alamin yang didalamnya terkandung kumpulan nilai ilahiyyah yang seharusnya dapat dipahami, dijadikan pegangan hidup bahkan juga menjadi prinsip dasar bagi pemeluknya. Menurut Farida, di Indonesia ini rakyatnya sangat beragam agama sehingga banyak juga pemahaman beragama yang berbeda-beda. Sikap yang harus dimiliki oleh masing-masing individu yaiitu sikap toleransi. Dalam agama Islam diajarkan tentang kedamaian, kemuliaan, memanusiakan manusia dan selalu mengarahkan dalam kebaikan agar berguna bagi bangsa dan negara. Namun dalam realitas kehidupan tidak sedikit antara pemluk yang satu dengan yang lainnya berbeda pemahaman yang mengakibatkan konflik terjadi. Akar kata multikultural merupakan kebudayaan yang dilihat dari fungsinya sebagai pedoman hidup manusia (Rahman \& Nuryana, 2019).

Pengembangan dunia modern terus menerus berkembang sangat cepat sehingga saat ini semakin mudah masyarakat menerima dan mencari informasi melalui teknologi bahkan tidak jarang banyak provikator yang ingin memecah belah bangsa ini dikarenakan keanekaragaman budaya di Indonesia. Indonesia sebenarnya mempunyai kekayaan budaya, kekayaan alam, dan kekayaan lainya yang ada di Indonesia ini sangat dibutuhkan yaitu pengelolaan dengan baik dari masyarakat dan pemerintah untuk memahami bahwa Indonesia

Keterkaitan antara pendidikan dan multikultural merupakan solusi atas realitas budaya dalam kehidupan berbangsa dan bernegara atas pluralitas dan heterogenitas. Pluralisme budaya di Indonesia diikat dengan semboyan bangsa Indonesia sendiri yaitu Bhinneka Tunggal Ika bahwasannya semboyan ini saat ini sering diabaikan karena kurang pemahamanya tentang pemahaman multikultural. Dalam proses pendidikan diajarkan bahwa sangat pentingnya memanusiakan manusia dengan begitu maka kita sebagai manusia mempunyai peran masing-masing yang harus dijalankan dengan baik. Salah satu solusi yang dapat dilakukan yaitu melalui pendidikan Multikultural untuk memperjuangkan multikulturalisme di Indonesia (Ibrahim, 2015).

\section{METODE}

Jenis penelitian ini menggunakan metode penelitian literatur atau kepustakaan (Library Research) yaitu dengan mengumpulkan data/informasi dari berbagai sumber. Menurut Sekaran, penelitian adalah kegiatan yang terorganisir, sistematiss, berdasarkan data, objektif, ilmiah dan dilakukan secara kritis untuk memperoleh suatu jawaban atau pemahaman yang mendalam atas suatu konflik. Dalam penelitian seharusnya mempunyai tahap sistemati yang terstruktur sehingga dapat memudahkan dalam kegiatan yang akan dilaksanakan dengan sempurna.

Penelitian literatur atau kepustakaan (Library research) ini bersifat kualitatif sehingga instrumen kunci dalam penelitian adalah human instrumen, seperti yang diungkapkan Nasution, yaitu dengan tahapan penelitian dari mengumpulkan data, menyajikan data, mereduksi data, memaknai data dan menyimpulkan hasil penelitian (Semiawan, 2010). Pengaturan natural sebagai sumber data secara langsung dan peneliti merupakan kunci instrumen dalam penelitian kualitatif. Penelitian ini bersumber dari jurnal dan buku yang menjelaskan tentang signifikansi Kebudayaan dalam Pendidikan (Nugroho, 2016).

HASIL \& PEMIBAHASAN

\section{Keberagaman Peserta Didik}

Keberagaman peserta didik disini yaitu berkaitan tentang keberagaman ras, etnis, budaya, dan bahasa dari masing-masing anak. Ketika dikelas anak membawa latar belakang, keterampilan, dan kebutuhan pendidikan yang berbeda-beda. Dalam hal ini diperlukan paradigma baru yaitu pendidikan multicultural, sebagai proses 
dalam pengembangan sikap dan perilaku, untuk saling menghargai perbedaan dan keberagaman budaya peserta didik atau heterogenitas dan menghargai budaya-budaya lain (Rahman \& Nuryana, 2019). Perbedaan disini merupakan kekayaan bangsa yang mana pendidikan multicultural diharapkan dapat meminimalisir sikap ekslusif dalam lingkungan sekolah.

Multikultural seharusnya lebih diperkuat dalam pendidikan, yang mencakup nilai-nilai dasar yang dibawa Pancasila berupa kejujuran, keadilan, persatuan, cinta tanah air, kerja keras, saling membantu dan gotong royong (Rahman, 2015). Seperti yang dijelaskan James Banks dalam (Mahfud, 2011) bahwa pendidikan multicultural ini sebagai pendidikan people of color, yangmana mengeksplorasi perbedaan yang ada sebagai anugerah Tuhan, dan bagaimana caranya kita menyikapai perbedaan tersebut dengan toleransi dan semangat egaliter (Rahman \& Nuryana, 2019).

Suatu sekolah yang mengelola pendidikan dengan menerapkan multikulktural pasti akan menghormati serta menghargai perbedaan yang ada antar warga sekolahnya seperti latar belakang agama, suku, ras, bahasa dan golongan. Menurut (Suryana \& Rusdiana, 2015), nilai-nilai inti dalam pendidikan multicultural itu ada 3, diantaranya:

a. Nilai demokratisasi, suatu nilai yang menyeluruh alam segala bentuk baik keadilan budaya, sosial, dan politik

b. Nilai humanism, nilai akan pengakuan pluralitas, heterogenitas, serta keragaman.

c. Nilai pluralism, pandangan yang mengakui akan keragaman dalam suatu bangsa (Rahman \& Nuryana, 2019).

Kesimpulan yang dapat diambil berdasarkan uraian tersebut yaitu pendidikan multicultural dalam pelaksanaanya adalah integrasi pelajaran nilai, pengetahuan, dan keterampilan dalam suatu masyarakat, serta disusun sesuai jenjang dan tahapan perkembangan peserta didik sehingga tercapainya nilai-nilai internalisasi. Pendidikan multicultural dikatakan berhasil jika nilai-nilai didalamnya dapat diinternalisasikan kedalam diri peserta didik dan di realisasikan dalam kehidupan kesehariannya.

\section{Strategi Pembelajaran untuk Keberagaman Peserta Didik}

Dalam suatu proses pendidikan disekolah, tentunya guru mempunyai peranan penting dalam kegiatan pembelajaran. Guru merupakan kunci pelaksanaan pendidikan multicultural kepada peserta didik sehingga dapat mendorong siswa mencapai keberhasilan. Materi yang disampaiakn oleh guru, kepribadian guru, serta strategi yang digunakan ketika mengajar sangat mempengaruhi proses belajar mengajar, yang diasumsikan peserta didik mempunyai keragaman perbedaan seperti latar belakang agama, etnik, budaya, ahasa, dan sebagainya (Munadlir, 2016).

Ketika pembelajaran didalam kelas, guru memilih strategi pembelajaran yang cocok dengan tujuannya. Ada banyak strategi yang bisa digunakan dalam kegiatan belajar mengajar dikelas, seperti diskusi, observasi, studi kasus, simulasi, bermain dalam peran, dan lain-lain. Misalnya ketika diskusi, guru dapat memperoleh informasi dari siswa tentang ragam budaya dan suku dari berbagai daerah, dengan ini peserta didik dan guru dapat bertukar pikiran tentang budaya apapun. Selanjutnya ada observasi dan studi kasus yang dilakukan melalui sebuah kegiatan yang mana dalam kegiatan ini diharapkan dapat mengamati proses sosial yang terjadi antara siswa dari kelompok tertentu dengan siswa lainnya, dan juga untuk mediasi jika ada konflik antar kelompok. Terakhir ada simulasi serta bermain dalam peran, strategi pembelajaran ini memfasilitasi peserta didik untuk bisa memerankan orang-orang yang memiliki agama, budaya, dan etnik yang berbeda dalam kesehariannya. Bisa juga dengan membuat suatu kegiatan sekolah yang membentuk kepanitiaan dengan keterlibatan aneka siswa yang mempunyai latar belakang agama, bahasa, budaya, dan etnik yang berbeda-beda (Munadlir, 2016).

Ketika menggunakan strategi mengajar peserta didik yang berbeda, tentunya seorang guru harus memperhatikan aspek-aspek yang ada dalam proses pembelajaran, diantaranya : pertama, guru mengajar bukan hanya menyampaikan kata-kata saja, namun juga memberikan kesempatan kepada peserta didik untuk mengexplore pengetahuan, sehingga peserta didik dapat mempunyai kajian yang lebih mendalam, kedua, pengembangan budaya terhadap peserta didik agar dapat dipahami dan disesuaiakan dengan realita peserta didik, ketiga, dalam pembelajaran harus bisa dikaitkan antara konsep baru dengan pengalaman yang sudah dimiliki oleh peserta didik Seorang guru dituntut untuk bisa menggunakan strategi pembelajaran yang kooperatif dengan saling ketergantungan dengan peserta didik, terjadinya interaksi antar guru dan peserta didik, keterampilan sosial, serta adanya efektivitas dalam pembelajaran kelompok. 
Strategi pembelajaran disini merupakan usaha atau cara untuk mencapai tujuan pembelajaran. Adanya strategi dapat mempermudah Kegiatan Belajar Mengajar (KBM), misalnya dengan adanya media dan sarana pembelajaran. Media pembelajaran yang digunakan dapat menggunakan storybook. Storybook merupakan sebuah buku yang berisikan cerita dan gambar-gambar mengenai lingkungan atau kondisi kehidupan (Widiyanto, 2017).

Didalam storybook dapat dijelaskan mengenai keberagaman budaya yang ada di Indonesia, misalnya dari tarian daerah, bahasa daerah, pakaian adat, lagu daerah, dan sebagainya. Dengan adanya media storybook ini diharapkan peserta didik dapat memahami keberagaman yang ada di Indonesia, dan peserta didik dapat meningkatkan rasa toleransi dalam kehidupan nyata. Selain itu, storybook diharapkan dapat memberikan pemahaman, keterampilan, dan sikap dalam bermasyarakat. Meskipun berbeda budaya, tetapi harus tetap menjaga kerukunan, persatuan, dan kesatuan.

Selain menggunakan media storybook, dapat menggunakan strategi cooperative learning tipe mind mapping. Dengan strategi tersebut membantu peserta didik untuk mengkonsep pikiran bersama kelompoknya masingmasing menjadi sebuat peta konsep pemikiran kelompoknya. Jadi, peserta didik dapat menyatukan berbagai pendapat dari masing-masing anggota kelompoknya. Selain itu, peserta didik juga dapat mengakui dan merespon adanya perbedaan antar peserta didik (Rahmatdani \& Rini, 2017).

Cara lain dapat menggunakan strategi pembelajaran card sort. Prosedur pelaksanaan strategi ini yaitu peserta didik diberikan masing-masing satu kartu yang berkaitan antara satu dengan lainnya. Setelah itu peserta didik diminta untuk mencari temannya yang memiliki kartu yang sama atau berkaitan. Kemudian peserta didik dapat mempresentasikannya didepan kelas (Silberman, 2009). Kartu yang diberikan kepada peserta didik mengandung materi mengenai keberagaman-keberagaman di Indonesia, misalnya satu kartu berisi "tarian Kecak" dan kartu yang berkaitan berisi "berasal dari Bali". Contoh yang lain misalnya satu kartu berisi "rumah adat honai" dan kartu yang berkaitan berisi "rumah adat khas daerah Irian Jaya". Dengan strategi card sort ini peserta didik akan lebih mudah menghafalkan materi dan dapat menghargai keberagaman-keberagaman di Indonesia (Puasawati, 2020).

Media pop-up book adalah buku yang didalamnya terdapat unsur gambar dua dimensi atau tiga dimensi yang dapat bergerak ketika halamannya dibuka. Pop-up book sangat menarik, mudah dimainkan, dan sangat praktis. Dengan adanya gambar yang bergerak ini dapat menambah semangat belajar dari peserta didik. Dalam pembelajaran misalnya materi mengenai keberagaman bangsaku, dapat dibuat gambar-gambar mengenai budayabudaya yang ada di Indonesia (Sholeh, 2019). Ada beberapa model yang bisa digunakan dalam pembelajaran karena keberagaman peserta didik, diantaranya:

a. Model behind the wall, model ini mengarah kepada agama secara kontekstual, jadi menurut Agus Nuryanto, model ini lebih mendalami agama yang dianut peserta didik sendiri. Model behind the wallbisa diterapkan pada peserta didik umur tujuh tahun pertama, namun jika berlanjut pada perkembangan usia berikutnya, dapat berdampak terhadap ketidaktauan akan tradisi dan budaya dari agama lain.

b. Model at the wall, model ini juga mengajarkan tentang agama lain tidak hanya agama yang dianut sendiri, menurut Christaini dalam (Rahman \& Nuryana, 2019), model ini dapat memperkaya pemahaman tentang iman dan menghargai agama lain. Pembelajaran dengan model ini bisa dilakukan dengan kegiatan diskusi tantang teks Al-Quran dan teks Al-Kitab dengan tokoh yang sama misalnya Isa dan Yesus. Pendidikan ini memberi kesempatan peserta didik dalam penguatan fitrah iman dan meningkatkan fitrah belajar dengan memahami dan mendialogkan kebenaran berdasar pemikiran masing-masing agama untuk mencari suatu kesamaan.

c. Model beyond the wall, model ini mengacu pada interaksi dengan lingkungan. Jadi sikap menerima dengan penganut agama berbeda dan menekankan sikap toleran terhadap agama lain untuk dapat berkontribusi dalam suatu aktivitas kemanusiaan. Misalnya mereka dapat bertemu dan berinteraksi dengan orang lain dalam keberagaman latar belakang sehingga dapat mengembangkan fitrah sosialnya dan memahami potensi fitrah hidup disekitarnya.

Model-model ini mengajarkan tentang perbedaan agama, suku, ras, budaya, dan golongan menjadi sebuah keunikan dan kekayaan bangsa yang menjadi sebuah dasar pengikat masyarakat didalamya. Dengan model-model tersebut diharapkan peserta didik dapat memahami dan mengamalkan ajaran agamanya masing-masing dan bisa terbuka mengenai perbedaan yang ada, serta diharapkan peserta didik menyadari bahwa musuh sebenarnya ialah kekerasan, korupsi, penistaan, ketidakadilan, dan sebagainya. 


\section{Refleksi Identitas Keberagaman Siswa di Ruang Kelas}

Mengajarkan kepada siswa tentang keberagaman menjadi tujuan utama di dalam kelas, karena sangat penting bagi siswa untuk belajar menyuburkan lingkungan yang heterogen, pasalnya ruang kelas ini merupakan persiapan bagi peserta didik dalam menghadapi dunia luar yaitu dunia kerja. Karena didalam ruang kelas, peserta didik berinteraksi dengan teman-teman yang berbeda. Jadi ketika masuk dunia kerja, siswa tidak bisa memilih rekan kerja seperti apa yang diinginkan. Peserta didik harus bisa menempatkan diri ketika berhadapan dengan sesorang yang mempunyai pengalaman dan pandangan yang berbeda.

Menyampaikan kepada siswa tentang keunikan yang mereka miliki, meyakinkan bahwa keunikan mereka bukanlah suatu masalah, namun malah menjadikan sesuatu yang berharga untuk kelas (Purnamasari, 2017). Ruang kelas disini berisi sejumlah peserta didik yang berbeda-beda, baik itu dari gaya belajar, sosioekonomi, latar belakang keluarga, agama.

Seorang guru ketika merefleksi keberagaman yang ada didalam kelas pasti mengahadapi sebuah tantangan. Guru melakukan upaya agar peserta didik itu tetap aman dan nyaman ketika berada di dalam kelas, sehingga peserta didik dapat dengan jujur mengenal latar belakang serta pengalamanya tanpa merasa dimarjinalisasi pengalamannya tidak sama dengan peserta didik lainnya. Peserta didik dapat secara terbuka mengungkapkan pengalaman-pengalaman individunya. Resiko sensitifitas yang dihadapi guru memang tinggi, karena perbedaan memang sulit, namun seorang guru tidak bisa menghindarinya. Hal pertama yang dilakukan ketika kita mengakui perbedaan yaitu dengan menyadari bahwa keunikan yang dimiliki orang lain dapat membuka pemikiran kita bahwa sebenarnya kita dapat menemukan kesamaan dalam diri kita, bisa berupa sifatnya yang mirip dengan kita, sehingga perbedaan-perbedaan yang ada akan membawa kita menjadi lebih kuat (Purnamasari, 2017).

Guru juga memberi kebebasan kepada peserta didik untuk saling mengajari satu sama lain bahwa perbedaan itu memang ada, serta membentuk perspektif dan identitas. Jika seorang guru telah mengajarkan kepada peserta didiknya tentang menghargai suatu keunikan, maka guru telah mengajarkan kepada peserta didik menghubungkan suatu ikatan yang akan membawa satu kesatuan. Dalam suatu program pendidikan, kita sepenuhnya yakin bahwa program ini didesain agar bisa memenuhi semua kebutuhan peserta didik tanpa memandang latar belakang, etnis, kultur, agama, status sosial, asal daerah, serta jenis kelamin. Menyiapakan peserta didik agar berhasil dalam pembelajaran tidak hanya dilakukan dengan berpikir kritis, namun ada berbagai cara yang harus dilakukan, yang terpenting kita mau dan mempunyai semangat dalam membawa perubahan dan keadilan sosial dalam tatanan masyarakat (Mahfud, 2011). Dalam satu sekolah, bahkan dalam satu kelas terdiri dari peserta didik yang sangat beragam, mulai dari perbedaan agama, ras, suku, etnis, dan sebagainya. Oleh karena itu, sebagai seorang guru harus memperhatikannya. Dalam proses pembelajaran ada tiga fase untuk menghadapi keberagaman tersebut (Kamal, 2018)

\section{Perencanaan}

Perencanaan dilakukan untuk mencapai tujuan yang telah ditentukan. Perencanaan yang dibuat harus mudah untuk dilakukan dan tepat sasaran, baik itu standar kompetensi, kompetensi dasar yang harus sesuai dengan keberagaman siswa dikelas. Dalam perencanaan, guru harus melakukan rancangan tindakan yang memuat beberapa hal, diantaranya menyusun tujuan pembelajaran, menetapkan materi, kegiatan pembelajaran, memilih media yang tepat, dan melakukan evaluasi. Selain itu guru juga menyusun indikator dan kritria dalam pembelajaran. Dan yang terakhir dilakukan pelatihan guru untuk pembuatan perencanaan, pelaksanaan pembelajaran, dan evaluasi pembelajaran (Alidawati, 2019).

\section{Pelaksanaan}

Tahap pelaksanaan merupakan tahap penerapan dari perencanaan yang sudah dibuat oleh seorang guru. Tahap pelaksanaan ini hakikatnya dalah Kegiatan Belajar Mengajar (KBM). Dalam tahap ini, ada beberapa hal yang harus diperhatikan oleh seorang guru yaitu dalam hal pendekatan, pemilihan strategi dan metode, dan prosedur pembelajaran. Hal-hal tersebut harus sesuai dengan keberagaman siswa dikelas. Seorang guru harus sadar dengan adanya keberagaman siswanya, sehingga nantinya Kegiatan Belajar Mengajar (KBM) akan disesuaikan. Jika Kegiatan Belajar Mengajar (KBM) disesuaikan dengan keberagaman dilakukan, maka akan mewujudkan rasa demokrasi, tolong menolong, toleransi, tenggang rasa, keharmonisan, keadilan, dan sebagainya. 
Evaluasi

Tahap evaluasi merupakan tahap pengukuran pemahaman siswa terhadap materi pelajaran yang sudah diajarkan oleh guru. Adanya tahap evaluasi ini, dapat mengukur kualitas dan kuantitas pencapaian tujuan pembelajaran. Tahap evaluasi juga meliputi analisis dari Kegiatan Belajar Mengajar (KBM) serta adanya perencanaan penyusunan perbaikan untuk Kegiatan Belajar Mengajar (KBM) selanjutnya (Widodo, 2019). Tahap evaluasi disebut juga dengan penilaian. Penilaian yang relevan antara lain (Karlina, 2016) adalah:

a. Penilaian kinerja peserta didik

Pada penilaian kinerja biasanya peserta didik diminta untuk melakukan tugas-tugas. Tugas tersebut misalnya menjawab, menulis, mengarang, mempresentasikan, melukis, melakukan eksperimen, dan sebagainya. Pada penilaian kinerja ini, biasanya peserta didik melakukannya secara individu, jadi dapat diketahui kemampuan tiap individu peserta didik.

b. Penilaian portofolio peserta didik

Penilaian portofolio merupakan penilaian perkembangan peserta didik dalam mengumpulkan suatu informasi-informasi dalam jangka waktu tertentu. Jadi, guru akan menilai peserta didik dari prosesnya dalam mendapatkan informasi-informasi tersebut sampai hasil akhir dari laporan portofolio yang disusun peserta didik.

c. Penilaian potensi belajar

Penilaian potensi belajar ini digunakan untuk mengukur kemampuan peserta didik yang dapat ia tingkatkan dengan bantuan guru maupun peserta didik lainnya.

d. Penilaian kelompok

Penilaian kelompok merupakan penilaian hasil kerja atau hasil diskusi suatu kelompok. Dapat juga memberikan penilaian individu bagi setiap peserta didik dalam kelompok tersebut dilihat dari keaktifan peserta didik dalam bekerja atau berdiskusi.

e. Penilaian proses

Penilaian proses merupakan penilaian yang digunakan untuk menilai pekerjaan dari peserta didik dan bertujuan untuk mengetahui cara peserta didik dalam memecahkan suatu masalah, serta cara peserta didik menunjukkan pengetahuan dan juga keterampilannya. Penilaian proses meliputi assesment kerja, assesment autentik, dan portofolio.

\section{SIMPULAN}

Keberagaman peserta didik diruang kelas yaitu keberagaman ras, etnis, budaya, agama, bahasa, dan golongan pada anak didik, dapat dilakukan dengan penanaman pendidikan multikultural sejak dini. Pendidikan multikulrural yaitu pendidikan people of color, yangmana mengeksplorasi perbedaan yang ada sebagai anugerah Tuhan, dan bagaimana caranya kita menyikapi perbedaan tersebut dengan toleransi dan semangat egaliter, dengan adanya pendidikan multikultural diharapkan dapat meminimalisir sikap ekslusif dalam lingkungan sekolah. Terdapat tiga fase yang dilakukan untuk merefleksi keberagaman yang ada di dalam kelas yaitu perencanaan, pelaksanaan, dan evaluasi.

\section{DAFTAR RUJUKAN}

Alidawati, A. (2019). Meningkatkan hasil belajar siswa dengan menggunakan media gambar berupa rumah adat tentang keragaman budaya di Indonesia pada pelajaran IPS Di kelas V SD Negeri 03 Kota Mukomuko. Indonesian Journal of Social Science Education (IJSSE), 1(1), 79-95.

Aziz, A. (2020). Melacak signifikansi pendidikan multikultural Islam di Indonesia. Andragogi: Jurnal Pendidikan Islam Dan Manajemen Pendidikan Islam, 2(3), 116-132.

Ibrahim, R. (2015). Pendidikan multikultural: Pengertian, prinsip, dan relevansinya dengan tujuan pendidikan Islam. Addin, 7(1), 129-154.

Kamal, M. (2018). Pengembangan Materi PAI berwawasan multikultural sebagai upaya menanamkan nilai-nilai keberagaman siswa SMKN 1 Ampek Nagari Kabupaten Agam. Edukasia J. Penelit. Pendidik. Islam, $13,26$.

Karlina, E. (2016). Penerapan model Problem Based Learning untuk meningkatkan kerja sama dan hasil belajar siswa kelas IV SDN Bhakti Winaya Bandung pada subtema kebersamaan dalam keberagaman. FKIP UNPAS.

Mahfud, C. (2011). Pendidikan multikultural. Pustaka Pelajar.

Munadlir, A. (2016). Strategi sekolah dalam pendidikan multikultural. Jurnal Pendidikan Sekolah Dasar Ahmad Dahlan, $2(2), 114-130$. 
Nugroho, M. A. (2016). Urgensi dan signifikansi pendidikan Islam multikultural terhadap kompleksitas keberagamaan di Indonesia. ATTARBIYAH: Journal of Islamic Culture and Education, 1(2), 179-210.

Puasawati, L. (2020). Penggunaan strategi pembelajaran Card Sort dalam meningkatkan pemahaman siswa materi keberagaman rumah adat tradisional di Indonesia mata pelajaran IPS kelas Va MIN 2 kota Surabaya. UIN Sunan Ampel Surabaya.

Purnamasari, I. (2017). Keragaman di ruang kelas: Telaah kritis wujud dan tantangan pendidikan multikultural. Harmony, 2(2), 130-138.

Rahman, A. (2015). Paradigma kritis Pancasila dalam dimensi pendidikan islam. Edukasia: Jurnal Penelitian Pendidikan Islam, 10(1), 125-143.

Rahman, A., \& Nuryana, Z. (2019). Pendidikan Islam di Era Revolusi Industri 4.0.

Rahmatdani, S., \& Rini, A. K. (2017). Penerapan Cooprative Learning Tipe Mind Mapping untuk meningkatkan hasil belajar siswa pada subtema kebersamaan dalam keberagaman. Didaktik: Jurnal Ilmiah PGSD STKIP Subang, 2(2), $367-395$

Semiawan, C. R. (2010). Metode penelitian kualitatif, karakteristik dan keunggulannya. Grasindo.

Sholeh, M. (2019). Pengembangan Media Pop-Up Book berbasis budaya lokal keberagaman budaya bangsaku siswa Kelas IV Sekolah Dasar. Jurnal Gentala Pendidikan Dasar, 4(1), 138-150.

Silberman, M. (2009). 101 strategi pembelajaran aktif. Terjemahan Oleh Sarjuli, Ammar Adzfar, Sutrisno, Dkk. Yogyakarta: Pustaka Insan Madani.

Suryana, Y., \& Rusdiana, A. (2015). Pendidikan Multikultural suatu upaya penguatan jati diri bangsa: Konsep, prinsip, dan implementasi. Pustaka Setia.

Widiyanto, D. (2017). Penanaman Nilai Toleransi dan Keragaman Melalui Strategi Pembelajaran Tematik Storybook pada Mata Pelajaran PPKn di Sekolah Dasar. Jurnal Pendidikan Kewarganegaraan, 7(2), 28-36.

Widodo, S. (2019). Melalui metode pembelajaran Diversity of Student Strategy Learning (Strategi Pembelajaran Yang Mempertimbangkan Keragaman Siswa) mampu meningkatkan prestasi belajar pada siswa kelas VIII-A semester ganjil Di SMP Negeri 3 Ngadirojo, Kabupaten Pacitan. Jurnal Edukasi Gemilang (JEG), 4(2), 63-68. 